\title{
Congenital absence of internal carotid artery: an unsuspected diagnosis
}

\author{
Nuno Ribeiro Costa, ${ }^{1}$ Ana Mafalda Reis, ${ }^{2}$ Delfim Duarte, ${ }^{1}$ Paula Azevedo ${ }^{1}$
}

${ }^{1}$ Department of Otorhinolaryngology, Pedro Hispano Hospital, Porto, Matosinhos, Portugal ${ }^{2}$ Hospital Pedro Hispano, Matosinhos, Portugal

\section{Correspondence to} Dr Nuno Ribeiro Costa, nunodanielcosta@gmail.com

Accepted 9 November 2016
CrossMark

To cite: Costa NR, Reis AM, Duarte D, et al. BMJ Case Rep Published online: [please include Day Month Year] doi:10.1136/bcr-2016218289

\section{DESCRIPTION}

A man aged 56 years, with a history of moderate sensorineural hearing loss, presented with a fast progressing loss of hearing discrimination in his right ear. The audiogram confirmed the moderate sensorineural hearing loss with a speech discrimination drop from $90 \%$ on the previous audiogram to $30 \%$.

An MRI of the brain revealed an absence of the right internal carotid artery (ICA). No signs of acute or chronic ischaemic changes were found in the brain parenchyma. Subsequently, a cervical and intracranial MR angiogram was performed, which revealed a complete absence of the right ICA and the first segment (A1) of the anterior cerebral artery (ACA) from ICA to the anterior communicating artery (figure 1). Both ACA arise from the left ICA. A CT scan of the brain and a CT angiogram of the supra-aortic arteries revealed a thinner common CA ending at the external CA (figure 2 ) and a hypoplastic carotid canal, at the right side (figure 3 ).

The absence of ICA is a rare congenital defect, with few cases reported in the literature. Most patients remain asymptomatic from a long period of time, mainly due to the collateral flow through the circle of Willis. ${ }^{1}$ The morphology of the carotid canal observed in the CT scan helps in the differential diagnosis with acquired occlusion of the ICA. ${ }^{12}$ An angiogram is required in patients with such defects since they present a higher incidence of intracranial aneurysms. ${ }^{3}$

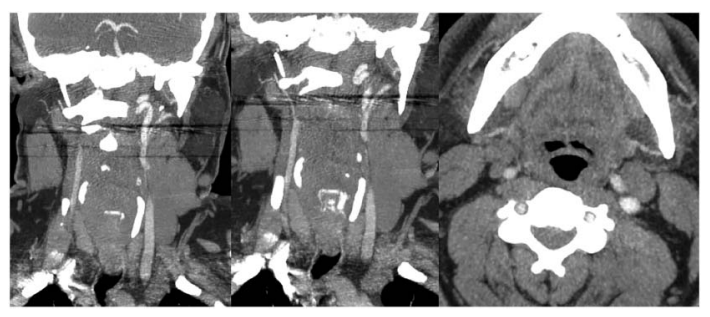

Figure $2 \mathrm{CT}$ angiogram of the supra-aortic arteries revealed a thinner common carotid artery (CA) ending at the external CA.

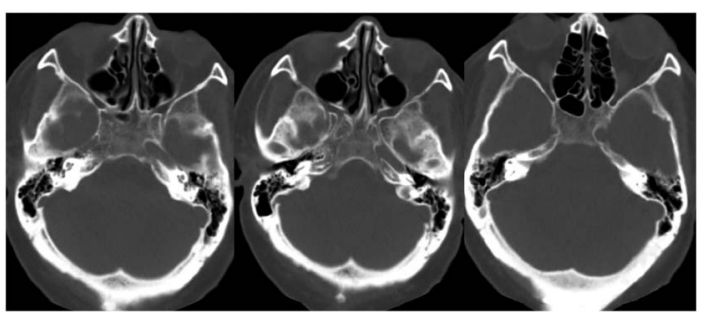

Figure 3 Brain CT scan revealed a hypoplastic carotid canal, at the right side.

The patient adapted hearing aid in the contralateral ear with significant improvement of his symptoms. Although no central cause for the progressive loss of speech discrimination was found, this diagnosis has important consequences for the patient and for possible future therapeutic or surgical interventions.

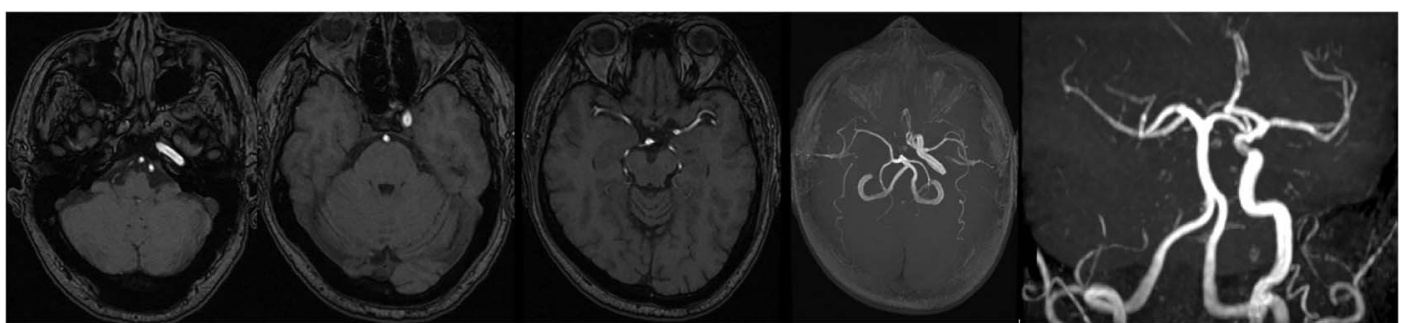

Figure 1 Cervical and intracranial MRI demonstrated a complete absence of the right internal carotid artery and the A1 segment of the anterior cerebral artery, with the posterior communicating artery supplying the middle cerebral artery on the same side. 


\section{Learning points}

- CT scan is important for the differential diagnosis between congenital absence of internal carotid artery (ICA) and acquired occlusion of the ICA.

- Congenital absence of ICA is more frequently unilateral. Most patients are asymptomatic due to the collateral circulation through the circle of Willis.

- Angiogram screening in patients with congenital absence is mandatory, due to the increase incidence of intracranial aneurysms.
Contributors NDRMdC is the main author. AMR helped with the interpretation of the CT scans and MRI. DD and PA revised the work and gave helpful insight.

Competing interests None declared.

Provenance and peer review Not commissioned; externally peer reviewed.

\section{REFERENCES}

1 Given CA II, Huang-Hellinger F, Baker MD, et al. Congenital absence of the internal carotid artery: case reports and review of the collateral circulation. AJNR Am J Neuroradiol 2001;22:1953-9.

2 Clarós P, Bandos R, Gilea I, et al. Major congenital anomalies of the internal carotid artery: agenesis, aplasia and hypoplasia. Int I Pediatr Otorhinolaryngol 1999;49:69-76.

3 Chen CJ, Chen ST, Hsieh FY, et al. Hypoplasia of the internal carotid artery with intercavernous anastomosis. Neuroradiology 1998;40:252-4.

Copyright 2016 BMJ Publishing Group. All rights reserved. For permission to reuse any of this content visit http://group.bmj.com/group/rights-licensing/permissions.

BMJ Case Report Fellows may re-use this article for personal use and teaching without any further permission.

Become a Fellow of BMJ Case Reports today and you can:

- Submit as many cases as you like

- Enjoy fast sympathetic peer review and rapid publication of accepted articles

- Access all the published articles

- Re-use any of the published material for personal use and teaching without further permission

For information on Institutional Fellowships contact consortiasales@bmjgroup.com

Visit casereports.bmj.com for more articles like this and to become a Fellow 